\title{
WHOLE BUSINESS SECURITIZATION IN EMERGING MARKETS
}

\author{
Claire A. HiLL*
}

\section{INTRODUCTION}

Whole business securitization, a transaction structure developed in England, has been used in Malaysia and is being considered for use in Hong Kong and Singapore. 'How does the structure add value? The answer is not obvious. Whole business securitization is, as the name implies, securitization of the whole business. Why are the structuring expenditures over and above those that would be incurred in a simpler debt and equity structure worthwhile? How does the firm become more valuable when it is placed into a securitization structure? In a typical securitization, a pool of like receivables is securitized. There is at least the promise of economies of appraisal and management. Explaining why placing a whole business-not only the firm's receivables, but also its plant, property and equipment, intellectual property, and all of its other assets-into a securitization structure adds value is, at first blush, a daunting challenge.

In this essay, I propose an explanation. Whole business securitization adds value by minimizing bankruptcy costs. A group of creditors provides the firm's entire debt funding; the group agrees, at the time the financing is provided, on their respective rights and obliga-

Copyright $(9) 2002$ by Claire A. Hill

* Associate Professor, Chicago-Kent College of Law. Thanks to Joji Takada, ChicagoKent College of Law, Class of 2003, for excellent research assistance. Thanks also to Charles Booth for his useful comments.

1. See Chito Santiago, Operating Company Securitization in Malaysia, THE AsseT OnLINE, July 2001, at http://www.theassetonline.com (last visited Apr. 12, 2002); WholeBusiness Securitization, Legal Media Group, July 31, 2001 (originally published in INT'L SECURITIZATION AND STRUCtured FinANCE REPORT) (quoting a Hong Kong attorney for a large U.S. firm who advised on the 1st Silicon Inc. deal: "There have been a number of inquiries from originators in different countries to structure whole-business deals to fit into various bankruptcy and insolvency regimes. Particularly those countries whose legal systems are based on common law, such as Malaysia, Singapore, and Hong Kong."), at http://www.gtnews.com/ articles_se/3414.html (last visited Apr. 12, 2002); Seeds of Securitization Emerging in Asia This Year, with Malaysia, Philippines, and Taiwan at the Forefront, AsSET SECURITIZATION REPORT, Feb. 26, 2001, at 13, 13, available at http://www.absnet.net (last visited Apr. 12, 2002). 
tions should the firm encounter financial difficulties. The transaction structure effectively includes an intercreditor agreement governing the relationship of all of the firm's creditors. The squabbling on the eve of bankruptcy that bankruptcy systems seek to prevent occurs well beforehand, when parties' incentives are not as opposed as they become when the firm faces, or is in, bankruptcy.

The whole business transaction structure is only possible in jurisdictions in which secured creditor priority is respected absolutely. The jurisdictions at issue are the United Kingdom and emerging markets such as Singapore and Malaysia, which inherited bankruptcy systems from the United Kingdom. ${ }^{2}$ In such jurisdictions, a secured creditor of all or substantially all of the assets of a company can control the company's insolvency. ${ }^{3}$ The secured creditors thus have the ability and incentive to formulate, at the outset of their financing, an effective intercreditor agreement that will be respected should their debtor become bankrupt.

2. Secured creditor priority is not sufficiently respected in the United States to permit whole business securitization. See Marion Leblanc-Wohrer, Growing Success for Whole Business Securitization, Asset SECURITIZATION REPORT, Feb. 19, 2001, at 18, 18, available at http://www.absnet.net (last visited Apr. 12, 2002).

In continental Europe and the US, the legal framework protects the debtor. Chapter

11 of the US Bankruptcy Code render [sic] traditional security arrangements by an originator nearly useless for the purposes of timely payment of interest and principal required by capital markets investors for highly rated securities. After the bankruptcy of the originator, the federal court has extensive powers to delay the creditors' rights to access their security.

$I d$. Bankruptcy lawyers routinely complain that violations of absolute priority are commonplace. As Douglas Baird notes, while " $[\mathrm{t}]$ he absolute priority rule allows the senior parties to insist on full payment, it also grants all junior parties those procedural protections necessary for a 'just reorganization.”' DOUGLAS G. BAIRD, ElEMENTS OF BANKRUPTCY 77 (3d ed. 2001) (characterizing these protections as "elaborate").

3. The Insolvency Act of 1986 is the relevant U.K. law. A secured creditor with charges over all or substantially all of the debtor's assets is allowed to appoint an administrative receiver. Insolvency Act, 1986, c. 45, § 29 (Eng.). The administrative receiver then manages and controls the company's assets; the main purpose of the receiver is to run the company for the benefit of the secured creditor (i.e., satisfy the debt owed to the secured creditor). See Ebo Coleman \& Stephen Roughton-Smith, Special Report: Non-Bankruptcy-Remote Issuers in Asset Securitisation, MoOdY's INVESTORS SERVICE, Mar. 22, 2001, at 3, 6-7. That being said, certain "preferential debts"-in particular, certain taxes, social security, and pension fund contributions-have priority over amounts owing to secured creditors. Insolvency Act, 1986, c.45, $\S$ 40, 386 (Eng.). Interestingly, the United Kingdom is considering paring back administrative receivership, and thereby scaling back the rights of secured creditors. See DEPT. OF TRADE \& IND., INSOLVENCY - A SECOND CHANCE (Cm. 5234, 2001), available at http://www.insolvency. gov.uk/cwp/cm5234.pdf (last visited Apr. 25, 2002); see also Mairin Burns, UK Insolvency Reform on the Way: Secured creditors' control to ebb under new rules, INVESTMENT DEALER'S DigEST, Aug. 6, 2001, at 12,12-13. 
In sum, whole business securitization offers a combination of economies: economies of scale and scope, and transaction costs savings of various types. Some of the economies are those frequently discussed in the literature but available in different ways. ${ }^{4}$ Other, more novel economies are made possible by features of the legal regimes in countries with English-style systems, features not contained in the U.S. legal system.

\section{BRIEF HISTORY AND OVERVIEW OF SECURITIZATION}

Securitization was developed in the United States in the 1970s. The structure contemplates the creation of a pool of cash flows; interests in the pool are sold to investors, and the proceeds are paid to the entity originating the cash flows. The first type of securitization transaction involved mortgages originated by banks. Since then, many other types of cash flows have been securitized, ${ }^{5}$ and transaction volume is now sizeable. ${ }^{6}$ Europe began using securitization in the 1980s, and it now has a sizeable transaction volume as well. ${ }^{7}$

In the late 1980s, emerging markets began using securitization. The first transaction was done by the Mexican telephone company TelMex. TelMex securitized its rights to receive payments from AT\&T for the Mexican portion of telephone calls made to Mexico from the United States-that is, the portion taking place between the United States-Mexico border and the Mexican destination. In the securitization transaction, TelMex sold its rights to the payments from AT\&T to a pool; the pool sold interests in the payments to investors, and paid to TelMex the amount it received from the investors. ${ }^{8}$ As

4. See discussion infra Section IV.

5. See generally Claire A. Hill, Securitization: A Low-Cost Sweetener for Lemons, 74 WASH. U. L.Q. 1061 (1996) (providing an overview of securitization transactions and relevant benefits).

6. 2001 was a stellar year for the U.S. asset-backed securitization market, with a record $\$ 350$ billion issued in asset-backed securities alone. Plain Vanilla Tastes Good: Ford's \$5 billion ABS deal sets the pace in a strong market, INVESTMENT DEALER'S DIGEST, Jan. 7, 2002, at 46, 46. Mortgage securitization volume will add significantly to the total.

7. As of June 2001, asset-backed security issues in Europe already totaled over $\$ 52$ billion (excluding commercial mortgage-backed security (CMBS) and collateralized bond obligation (CBO) deals). ABS Issued Outside of the US, AsSET-BACKED ALERT, June 30, 2001, available at http://www.abalert.com/Public/MarketPlace/Ranking (last visited Apr. 12, 2002).

8. Claire A. Hill, Latin American Securitization: The Case of the Disappearing Political Risk, 38 VA. INT'L L.J. 293, 307-08 (1998). 
happened in the United States, subsequent securitization transactions have involved many different types of cash flows.'

\section{DESCRIPTION OF WHOLE BUSINESS SECURITIZATION}

The whole business securitization structure first emerged with the securitization of nursing homes in the United Kingdom in the mid-1990s. ${ }^{10}$ Since then, there have been several transactions in the United Kingdom, ${ }^{11}$ a few in Australia ${ }^{12}$ and New Zealand, ${ }^{13}$ and now one transaction in Malaysia. ${ }^{14}$ Investment bankers hope that as financial markets become familiar with the structure, whole business securitization will increasingly be a financing option for suitable companies. One banker at Nomura, the bank that arranged the Malaysian deal, said "we've broken ground in Asia, and have lawyers and international rating agencies on board in structuring this kind of a deal."15 And Vinod Kothari, a leading expert on securitization in emerging markets, said that the Malaysian transaction "will act as a notable precedent for similar issues in Asia."

\section{A. Whole Business Securitization}

The salient features of whole business securitization are as follows. A special purpose vehicle (SPV) is formed to make a loan to a

9. See generally id. (describing the successful introduction of securitization in Latin America).

10. Nursing Homes Securitization Gathers Steam in the UK, INVESTMENT DEALER'S DIGEST, Dec. 8, 1997, at 6, 6 (discussing nursing home securitization deals that focused on the collateralization of future lease and rent payments).

11. U.K. transactions have involved the London City Airport, Madame Tussaud's Wax Museum, and pubs and taverns. See This year's model, PROJECT FIN., Mar. 1, 2000, at 32, 32-33; Conor Downey, Whole Business Securitization Comes of Age, INT'L FIN. L.R., Sept. 1999, at 8, 8-12; Leblanc-Wohrer, supra note 2, at 18.

12. For example, one transaction involved "notes . . . backed by a pool of fixed-rate ... lease contracts with underlying collateral of equipment and" automobiles. Luke Elder, Commentary: Securitization of Operating Assets in Australia and New Zealand, STANDARD \& POOR's, July 2, 2001, at http://www.standardandpoors.com/australiaNZ/forum/marketcommentary/articles/070301_secassets.html (last visited Apr. 12, 2002).

13. One transaction in New Zealand involved notes backed by a pool of commercial fixed rate operating lease contracts with underlying collateral of passenger vehicles, utilities, and light trucks. See id.

14. See infra notes 26-27 and accompanying text.

15. See Santiago, supra note 1 , at 4.

16. Rob Davies, Leading Indian Expert Advocates ABS in Asia, FinANCEAsIA.COM, Nov. 27, 2001, at http://www.financeasia.com (last visited Apr. 12, 2002). Note, too, that Moody's expects whole business securitization to be an important part of the European securitization market. Moody's: Global ABS Issuance to Remain Strong in 2002, Despite Credit Crunch, MoODY's INVESTORS SERVICE, Feb. 8, 2002. 
company that is seeking financing (the borrower). The SPV makes the loan, using money it raises from investors. It receives as security for repayment of the loan fixed and floating charges over all or substantially all of the borrower's assets, and thus becomes a secured creditor of the borrower. Under the bankruptcy laws of the United Kingdom and other jurisdictions that have used this transaction structure, secured creditors of a company approaching insolvency can appoint a receiver who controls and manages the company purely for the creditors' benefit. ${ }^{17}$ The absolute priority granted to holders of the fixed and floating charges to appoint an administrative receiver is respected absolutely, unlike in the United States, where absolute priority is routinely violated. ${ }^{18}$

The SPV has a security trustee who acts on behalf of the investors. Should the borrower become bankrupt, the trustee has extensive powers. ${ }^{19}$ Indeed, in some cases, alternate uses for the company's assets have already been considered and strategies to explore those uses have been included in the transaction documentation. ${ }^{20}$

Other features of the whole business securitization transaction structure are typical securitization features, such as liquidity facilities and other types of credit enhancement. Interestingly, while standard securitizations are very often done using multiple tranches, wherein some investors are paid first and others are paid afterwards, whole business securitizations sometimes are done using only one tranche, especially where the transaction size is small. ${ }^{21}$

Although the whole business transaction structure is nominally a securitization, it is actually a hybrid between a true securitization and

17. See Insolvency Act, 1986, c. 45, § 32 (Eng.).

18. See, e.g., id.; Coleman \& Roughton-Smith, supra note 3, at 6-7. Cf. BAIRD, supra note 2, at 74-78.

19. For a general discussion of trustees in securitization, see HILL, supra note 5, at 1098-99.

20. See generally Benedict Pfister, Special Report: Whole Business Securitizations: A Unique Opportunity for UK Assets, MOODY's INVESTORS SERVICE, Oct. 19, 2000 (discussing how the ability to use a business's assets in a different capacity allows a delinkage between the securitized debt and the borrower's industry or business (e.g., nursing homes or pubs may be converted into residential properties or general retail use) resulting in a more highly rated issue).

21. The 1st Silicon transaction, see discussion infra Part III.B, has only one tranche, as does the City Aviation Finance Limited transaction, see This year's model, supra note 11, but the Really Useful Theatres Limited Asset Backed Notes transaction, see Sunil Gidoomal \& Charles Gamm, Pre-Sale Report: Really Useful Theatres Finance Limited Asset Backed Notes, MoODY's InVESTORS SERVICE, Oct. 16, 2000, at 1, had four tranches, as did the Tussaud Group transaction. Downey, supra note 11, at 9. And the Punch Funding II transaction had six tranches. See Benedict Pfister, Pre-Sale Report: Punch Funding II Limited, MoOdy's InVESTORs SERVICE, May 24, 2000. 
a corporate credit. $^{22}$ Insofar as it depends on the continued cashgenerating abilities of the operating company, it resembles a corporate credit. It also somewhat resembles future flows securitization, which, as the term implies, securitizes cash flows that will be generated in the future. The more typical securitizations securitize existing flows, flows already owing at the time they are securitized.

Many types of businesses are unsuitable for whole business securitization. ${ }^{23}$ A good candidate is a stable business with a long operating history, fairly predictable cash flows, and managers who are not

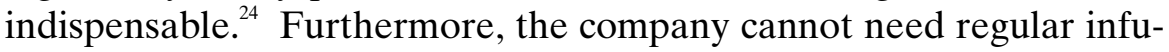
sions of additional financing; it scarcely seems worthwhile to, in effect, negotiate an elaborate intercreditor agreement among the company's creditors and then have to seek new financing from others not party to the agreement. ${ }^{25}$

\section{B. Malaysian Whole Business Securitization}

The Malaysian whole business securitization transaction, 1st Silicon (Labuan) Inc., was completed in June 2001. ${ }^{26}$ The borrower in the transaction, 1st Silicon (Malaysia) Sdn., established Malaysia's first $200 \mathrm{~mm}$ silicon wafer fabrication plant. (Silicon wafers are sold to the semiconductor industry.) The investors, who purchased notes from the SPV, received the benefit of fixed and floating charges over all of the borrower's assets. ${ }^{27}$

This transaction violates some of the above-mentioned guidelines for whole business transactions. The borrower is a start-up company, not presently generating much cash flow. Furthermore, the semiconductor industry itself is volatile; the borrower may have difficulty achieving stable and predictable cash flows. ${ }^{28}$ What made the transaction possible was a guarantee from the Sarawak Economic Development Corp. and a letter of support from the State Govern-

22. See generally Elena Folkerts-Landau, Commentary: Principles for Analyzing Structured Finance/Corporate Hybrid Transactions, STANDARD AND POOR's, July 2, 2001 (describing the principles developed by Standard and Poor's for rating structured finance/corporate hybrid transactions), at http://www.standardandpoors.com/emarketing/structuredfinance/copy070201_ hybrid.html (last visited Apr. 12, 2002).

23. See Leblanc-Wohrer, supra note 2, at 1.

24. Folkerts-Landau, supra note 22, at 6.

25. Id.

26. Santiago, supra note 1 , at 1.

27. Id. at 2 .

28. Id. at 3; Neal Shah \& Stephen Roughton-Smith, Pre-Sale Report: 1st Silicon (Labuan) Inc., MOODY's InVESTORS SERVICE, May 25, 2001, at 2. 
ment of Sarawak..$^{29}$ Because of the guarantee and letter of support, the transaction was able to obtain an investment grade rating, the first Malaysian corporate bond issue to do so without an "explicit link" to the Malaysian sovereign. ${ }^{30}$

\section{CAPITAL STRUCTURE THEORY: HOW DOES WHOLE BUSINESS SECURITIZATION ADD VALUE?}

The starting point for inquiries into transaction structures is Modigliani and Miller's capital structure irrelevance theorem. ${ }^{31}$ The theorem shows that in a perfect world with no transaction or agency costs, a firm's capital structure (and, by extension, the transaction structures it uses to effectuate that capital structure) cannot add value. ${ }^{32}$ The task is to identify the costs that a particular transaction structure helps reduce. ${ }^{33}$ Among the types of benefits commonly ascribed to transactions are information cost, transaction cost, or agency cost benefits. For instance, a transaction structure might allocate duties to economize on, and take advantage of, specialization in monitoring. ${ }^{34}$ Or the structure might constrain a firm so as to act in creditors' interests in certain respects, thus lowering their discount for the firm's potential misbehavior.

An explanation I have given for securitization is that it can reduce overall information costs to the firm's investors. Securitization

29. Because of this sub-sovereign bond transaction element, the transaction could further be classified as a triple hybrid. Santiago, supra note 1, at 3 .

30. Nomura Completes US $\$ 250$ Million Floating Rate Note Issue for Malaysia's 1st Silicon, EDA TOOLS CAFÉ, June 15, 2001 (noting that the borrower is itself forty-eight percent owned by an entity that is majority owned by the state of Sarawak), at http://www.dacafe.com/ DACafe/NEWS/ICNews/20010615_0002.html (last visited Apr. 12, 2002); see also Shah \& Roughton-Smith, supra note 28, at 2 .

31. See generally Franco Modigliani \& Merton H. Miller, The Cost of Capital, Corporation Finance and the Theory of Investment, 48 AM. ECON. REV. 261 (1958) (discussing the significance of capital structure in a perfect market).

32. Id. at 276 .

33. Some scholars argue that transaction structures like secured debt and securitization do not add value - that they simply constitute "grabs" from those who are not at the bargaining table, unsecured creditors who did not provide in their agreements for the firm's use of secured debt, and tort and judgment creditors. See, e.g., Lucien Bebchuk \& Jesse Fried, The Uneasy Case for the Priority of Secured Claims in Bankruptcy, 105 YALE L.J. 857, 934 (1996); Lynn LoPucki, The Death of Liability, 106 YALE L.J. 1, 15-16, 23 (1996). A final observation: For those who believe that creditors who are not "at the table" are being hurt by transaction structures that give creditors who are at the table preferred treatment, a transaction structure like whole business securitization exacerbates the problem.

34. This is a standard explanation given for secured debt. A critique of this explanation, and a more comprehensive explanation of secured debt is made in Claire A. Hill, Is Secured Debt Efficient?, 80 TEX. L. REV. 1117 (forthcoming May 2002). 
helps a firm separate assets that are less costly to appraise from the remainder of the firm, thus confining costly inquiries about the firm's residual risk to a smaller group of assets. ${ }^{35}$ Another explanation I have given is regulatory cost-reduction: using securitization, a firm can obtain more favorable regulatory treatment.

Neither asset-segregation nor regulatory cost-reduction seems like a promising explanation for whole business securitization. Asset segregation is clearly ruled out, since the assets are left together rather than segregated. An agency cost explanation doesn't, at first blush, seem promising either since whatever constraints are imposed on the borrower through the structure could also be imposed through a simpler and cheaper secured loan structure.

Indeed, whole business securitization seems particularly difficult to explain. It should be particularly expensive, not only because it is in its infancy, but also because the differences in the assets and cash flows means each transaction requires extensive and costly individual tailoring. ${ }^{36}$ Moreover, the transaction necessarily contemplates careful (that is, expensive) monitoring of the company, since the company's continued performance in generating cash flows is critical. ${ }^{37}$

Two benefits that may be available are generic, applicable to many different types of securitization. One benefit may be a specialization benefit, as entities learn how to be the active trustees contemplated in these types of transactions. Trustees learn how to monitor and perform other relevant tasks cost-effectively for groups of investors. Specialization in whole business securitization transactions may not yet have progressed to the point that it yields an economy; however, parties hoping to promote a market in these types of transactions might anticipate amortizing their costs over future transactions, and hence might provide services in a particular transaction at prices reflecting more experience with the type of transaction than they have.

The other generic benefit is that securitization investors are capital markets investors, providing cheaper sources of financing than banks. The benefit to whole business securitization transactions might be particularly large, since a firm doing such a transaction is likely to obtain the bulk of its financing in that transaction. ${ }^{38}$ The

35. Hill, supra note 5, at 1066; see also id.

36. See Folkerts-Landau, supra note 22, at 1.

37. Id.

38. Certainly, a firm using whole business securitization is not able to get any more secured debt, since the transaction secures all its assets. And, given that the securitization is also of all 
larger a proportion of its financing a firm obtains on the capital markets, the more the firm has saved by its ability to access the capital markets.

But what seems likelier as a source of benefit is the ex-ante intercreditor agreement among the investors, with its careful planning for the firm's bankruptcy. Creditors take the possibility of a firm's bankruptcy into account in the terms on which they lend. They multiply the probability of bankruptcy by the expected cost of bankruptcy. If either of those numbers can be reduced, the creditors will offer the firm better financing terms.

In the United States, bankruptcy is very costly. ${ }^{39}$ Because the law does not allow any creditor to absolutely assure its position in the hierarchy of creditors, an appreciable amount of expensive lawyer time, as well as considerable energy of all parties concerned, is spent on the negative-sum game of dividing (or establishing entitlement to) an ever-dwindling set of assets. ${ }^{40}$ Secured creditors have de jure priority and contractual seniority and subordination agreements may be respected. Still, both the rules and the conduct of the proceeding make jockeying by all parties worthwhile.

By contrast, bankruptcy law in the United Kingdom and in countries which have based their bankruptcy law on U.K. law gives secured creditors de facto as well as de jure priority. Secured creditors who have a security interest in all or substantially all of a bankrupt firm's assets (as the whole business securitization trustee does, on behalf of the creditors) have the right to appoint an administrative receiver who runs the company for their benefit. ${ }^{41}$ An agreement among the secured creditors is hence worthwhile because it divides stable and determinate rights. Moreover, since it is likely that the secured creditors in a whole business securitization transaction comprise all the firm's creditors (except perhaps for a few trade creditors) the agreement effectively governs what will happen to the firm during

the firm's present and future cash flows, it is hard to imagine from what sources other lenders could hope to be repaid.

39. Older data suggests a figure for bankruptcy costs of $3.1 \%$ of the book value of debt plus the market value of equity. Lawrence A. Weiss, Bankruptcy Resolution: Direct Costs and Violation of Priority Claims, 27 J. FIN. ECON. 285, 286 (1990). It is difficult to know whether that figure is accurate now. But nobody doubts that the costs are significant.

40. This uncontroversial characterization stems from my own practice experience, and my discussions with many bankruptcy practitioners.

41. Insolvency Act, 1986, c. 45, $\S 32$ (Eng.) ("Where application is made to the court to appoint a receiver on behalf of the debenture holders or other creditors of a company which is being wound up by the court, the official receiver may be appointed."). 
the bankruptcy; there need not be the costly squabbling before and during bankruptcy that characterizes U.S. bankruptcy. The increment of improvement achieved by the secured creditors may not be very large, given their favorable position under the bankruptcy laws in any event; however, to be worthwhile it only needs to exceed the associated costs.

An objection to my explanation suggests itself: in emerging markets countries, enforcement of laws is sufficiently uncertain that investors can scarcely be assured that their intercreditor agreement will be enforced. I have three responses. First, all that is needed is an incremental benefit over the alternative. The creditors do not need complete assurance that their agreement will be upheld. They only need to think that the securitization transaction increases their expected recovery by more than the associated structuring costs. Second, to the extent that government guarantees are involved, the government may have a strong incentive to influence its own courts to enforce the agreement. The government of an emerging markets country hoping to attract foreign investment might, in any event, have such an incentive, even if it has not given a guarantee; a guarantee might strengthen that incentive. ${ }^{42}$ Third, at this early stage, when whole business securitization in emerging markets is in its infancy, the creditors' better terms - the terms that make the transaction structuring expenditure worthwhile - may not be because of the valueadded of the intercreditor agreement. Rather, the creditors may simply be relying on the government's guarantee, a guarantee that the government provides at a subsidized rate to attract more investment to the region. Once there is appreciable investment by capital markets investors, the payoff to predictable enforcement of bargains will increase, which may in itself motivate such enforcement.

\section{CONCLUSION}

Whole business securitization is potentially another arrow in a firm's quiver of financing options. But how useful is it likely to be to emerging markets firms? At this early stage, when emerging markets are only beginning to explore whole business securitization, most, if not all, deals likely will involve a government guarantee of some sort. On a pure economic basis, the transaction will not earn its keep.

\footnotetext{
42. The government guarantee may be available for less than the price of the credit enhancement that the guarantee provides, because the government can reduce the possibility that the guarantee will have to be collected upon.
} 
Indeed, there are many reasons to suppose that whole business securitization is no panacea for emerging markets firms. The moderate term aim is for the transaction structure to earn its keep without the need for a guarantee. The firms have to be good firms, capable of servicing their debt. Securitization in emerging markets firms has historically sought to take high quality cash flows and segregate them from the possibility of appropriation by a sovereign: the profile of securitization uses has been "very good firm, bad government." no segregation from the sovereign is possible, so the value of the transaction cannot come from that source. ${ }^{44}$ Moreover, the "very good firms" that typically use securitization in emerging markets don't need to be that good, because they're not seeking to meet all their financing needs through the securitization transaction structure. They only need to have some good receivables that they can use to obtain low-priced financing. ${ }^{45}$ By contrast, the firms in whole business transactions aren't just financing some of their good assets-they are financing all their assets. The set of firms that can sell interests in all their assets on the capital markets is far smaller than those that simply have some high-quality assets they can finance on the capital markets.

But an additional financing option surely cannot be bad, even if it is rarely used. Investment bankers thrive on innovation, and capital markets are willing to exploit even the smallest increments of valueadded; if the Malaysian deal is successful, emerging markets should begin to make more use of whole business securitization as well as other innovative transaction structures.

43. Hill, supra note 8 , at 318 .

44. Note, however, that increasingly, securitization transactions in emerging markets have contemplated more exposure to the sovereign, as more transactions involving domestic cash flows and domestic investors have been completed. See Sam Littlewood, Tomorrow's Cash Today, CFO ASIA, Feb. 1999, at 70, 70-71 (surveying the use of asset backed securitization in Asia), available at http://www.cfoasia.com/archives/9902-70.htm (last visited Apr. 12, 2002).

45. It is true, though, that those receivables are often future flows receivables, to be generated in the firm's future operations, thus requiring that the firm has to stay good enough to generate those receivables. See Hill, supra note 8, at 318-19. 